\title{
Ent examination and cerumen removal in Letjen Jamin Ginting Junior High School, Berastagi
}

\author{
Farhat Farhat $^{1 *}$, Elvita Rahmi Daulay ${ }^{2}$, Dewi Masyithah Darlan ${ }^{3}$ \\ ${ }^{1}$ Department of Otorhinolaryngology-Head and Neck Surgery, Faculty of Medicine, \\ Universitas Sumatera Utara \\ ${ }^{2}$ Department of Radiology, Faculty of Medicine, Universitas Sumatera Utara \\ ${ }^{3}$ Department of Parasitology, Faculty of Medicine, Universitas Sumatera Utara \\ *Email: farhat@usu.ac.id
}

\begin{abstract}
Diseases of ear, nose, and throat (ENT) are common diseases in the world. The diseases are essential due to morbidities, which affect the physiological functions in the head and neck region. Cerumen impaction is the most common finding disease of ENT in children. The community service was done to find the distribution of ear, nose, and throat examination results of students in Letjen Jamin Ginting Junior High School, Berastagi, especially cerumen impaction which then were treated with cerumen removal. The community service also aimed to increase student's knowledge about ENT disease. The ENT examination was done to 188 students. The students with cerumen impaction were treated with cerumen removal. The students also educated about ENT disease to improve knowledge about ENT disease. Among 188 students, the number of male students was more than female with 98 students $(52.1 \%)$, where 76 students $(40.4 \%)$ were 14 years old. 150 students $(79.8 \%)$ did not have any complaint about their ear, nose, and throat. Ear fullness was a common chief complaint from the students with 15 students $(8.0 \%)$. Ear disease was a frequent disease with 44 students $(47.3 \%)$ and cerumen impaction as the most common findings with 43 students (22.9\%). In ENT disease education, the evaluation was done with the highest result was get by 8 students with $80 \%$ corrected answers. Ear disease had high prevalence with cerumen impaction as the most common findings of ENT examination.
\end{abstract}

\section{Keywords: Cerumen Impaction, Cerumen Removal, ENT Disease}

\section{INTRODUCTION}

The health of children, including the ear, nose, and throat area is vital for their development and affects the ability to get and understand knowledge. Diseases of ear, nose, and throat (ENT) are common in the populations of the world (Sigdel and Nepali, 2012; Verina, 2015). The understanding of the diseases is important due to their morbidities, which causes dysfunction of physiological functions of the head and neck region. The morbidities are hearing loss, difficulty in breathing, dysphagia, difficulty in speech, smell dysfunction, and loss of taste (Fasunla et al., 2013).

Ear disease is the most common disease in developing countries and suffered mostly by children (Sigdel and Nepali, 2012; Verina, 2015). The most common finding of ear disease is cerumen impaction (Hussein et al., 2018). Cerumen impaction occurs up to $6 \%$ in the general population and becomes the reason for many visits in primary care consultations (Brkic, 2010). Cerumen impaction affects about $10 \%$ of children and $5 \%$ of adults. The disease is frequently underdiagnosed and not treated, although it has a relatively high proportion (Fullington et al., 2017).

Earwax, also known by the medical term as cerumen, is a gray, orange, red or yellowish waxy substance that released into the ear canal of humans and other mammals. Protects skin from the human ear canal, assisting in cleaning and lubrication, and also protects against bacteria, fungi, insects, and water (Snow and Wackym, 2009). 
Farhat Farhat et.al. Ent examination and cerumen removal in Letjen Jamin Ginting Junior High School

Cerumen is an ordinary substance in the ear canal which is the secretion product of sebaceous gland and ceruminous gland in the one-third of external ear canal together with the desquamation of ear canal epithelium (Schwartz et al., 2017; Stránský et al., 2011). The using of cotton bud or hearing aid used lead to the accumulation of cerumen or cerumen impaction (Wright, 2015; Eskelinen et al., 2014; Ulaganathan and Shalini, 2015).

Cerumen impaction is usually caused by the inability of the ear to cleanse itself naturally or due to inserting of an object which caused ear wax deeper into the ear canal and led to the hearing loss. Factors that increase the incidence of impaction as the ear canal is narrow and tortuous, stiff hair or obstructive lesions channels, example: exostosis, the use of cotton swabs to clean the ear canal, the growth of dense hair in the ear canal, the use of hearing aids, and handicapped intellectual (Brkic, 2010). Wax which forms clumps that accumulate in the ear canal can cause conductive hearing loss. Especially when the ear entered the water when bathing and swimming, cerumen will be inflated and caused fullness sensation in the ear.

Cerumen itself is useful in the protection of the ear canal. Cerumen has antimicrobial properties that take part in the first line of human protection system (Schwaab et al., 2011).

Ear canal cleaning occurs as a result of the "conveyor belt" process of epithelial migration, aided by jaw movement. The cells are formed in the middle of the tympanic membrane migrate out of umbo (at a rate proportional to the growth of nails) in the wall of the ear canal, and move towards the entrance of the ear canal. The cerumen in the ear canal is also carried outwards, taking with it any particles that may have been gathered in the canal. Jaw movements help this process by unplugging the debris attached to the wall of the ear canal, increasing the likelihood of its expulsion. Cerumen is expelled by normal ear skin migration and jaw movement (Poulton et al., 2015; Tuli, 2013).

The symptoms of cerumen impaction are ear fullness canal, hearing loss, tinnitus, itchy ear, and ear pain. The hearing loss which resulted to due cerumen impaction is caused by conductive hearing loss (Pensak and Choo, 2014, Schwartz et al., 2017, Krouse et al., 2017, Eziyi et al., 2011). The diagnosis of cerumen impaction is based on history taking, physical examination such as ear canal inspection, otoscopy and hearing test with a tuning fork (Akotey et al., 2017; Stewart and Selesnick, 2011).

The treatment for cerumen impaction was cerumen removal done by a physician. Cerumen removal could be done by manual extraction, irrigation, and chemical substance use. The manual extraction was using cerumen hook or suction. A chemical substance such as glycerin or hydrogen peroxide was used to soften the harden cerumen (Snow and Wackym, 2009; Linstrom and Sclafani, 2015; Griffin and Anderson, 2019).

There are three methods recommended removal: cerumenolytic agents, irrigation, and manual removal. Cerumenolytic agent, also known as ear wax drops, liquid solutions that help thin, soften, break, and/or dissolve the ear wax. These drops are usually water-based or oil, with a water-based solution that is most commonly used. Hydrogen peroxide, acetic acid, docusate sodium, and sodium bicarbonate were the typical materials found in water-based cerumenolytics. Common ingredients in oil-based cerumenolytics were peanut, olive, and almond oil. Typically, up to five drops are used at a time of one to two times daily for three to seven days. They could either be used alone or in conjunction with procedures such as ear irrigation (Sevy and Singh, 2017).

Another safely and effectively method to remove unwanted cerumen is irrigation. There are many variants of irrigation methods used in the clinical setting. In general, warm water alone or a 50/50 mix of water and hydrogen peroxide flushed into the ear canal with a basin underneath with a syringe. Another option is a standard oral jet irrigator, with or without a modified tip. Although these methods are inexpensive, the potential to cause trauma, including perforation of the tympanic membrane is high when not correctly 
Farhat Farhat et.al. Ent examination and cerumen removal in Letjen Jamin Ginting Junior High School

done. An ear irrigator tip can be used to mitigate the risk. There are electronic irrigators available as well; however, there are no controlled trials to compare the different irrigation methods.

Manual removal is the final method recommended by the American Academy of OtolaryngologyHead and Neck Surgery to remove unwanted wax. Manual removal often requires special instrumentation for better visualization, such as a binocular microscope or handheld speculum. Cerumen removal device involves a metal or plastic loop or spoon, curettage, or alligator forceps. Some products have illuminated tips to help visualize during the procedure. The advantage of this method is the low risk of infection because the ear canal is not exposed to moisture. However, pose a small risk of perforation and local trauma, especially if the patient is not cooperative. This method also requires more clinical skills (Sevy and Singh, 2017).

The ENT examination was done in Letjen Jamin Ginting Junior High School, Berastagi as a partner of community service. The students become the object of treatment. The result will present the distribution of ear, nose, and throat examination's result, including cerumen impaction as ear disease. Cerumen removal was done for the students with cerumen impaction. Besides, the education about ENT disease to the delegation of the students was done to increase the knowledge about ENT disease.

\section{METHOD}

The implementation method offered from the community service program is divided into several stages including review of partner area locations with the headmaster, education about ENT disease, and the examination of ear, nose, and throat to get the distribution of ENT examination's result of the students. The materials of the education were about anatomy and common diseases of ear, nose, and throat, which include the definitions, etiology, clinical manifestations, and the treatment. The ENT examination and treated the students with cerumen impaction with cerumen removal was done in this community service.

\section{RESULTS AND DISCUSSION}

ENT examinations and cerumen removal were done in Letjen Jamin Ginting Junior High School, Berastagi. Table 1. shown the characteristics of the students in the partner of community service.

Table 1. Characteristics of Students in Letjen Jamin Ginting Junior High School, Berastagi

\begin{tabular}{lcc}
\hline \multicolumn{1}{c}{ Characteristics } & n & \% \\
\hline Gender & & \\
Male & 98 & 52.1 \\
Female & 90 & 47.9 \\
\hline Age (years old) & & \\
11 & 1 & 0.5 \\
12 & 27 & 14.4 \\
13 & 73 & 38.8 \\
14 & 76 & 40.4 \\
15 & 10 & 5.3 \\
16 & 1 & 0.5 \\
\hline Chief Complaint & & \\
Nothing complaint & 150 & 79.8 \\
Ear fullness & 15 & 8.0 \\
Nasal congestion & 4 & 2.1 \\
Itchy ear & 5 & 2.7 \\
Dysphagia & 6 & 3.2
\end{tabular}


Farhat Farhat et.al. Ent examination and cerumen removal in Letjen Jamin Ginting Junior High School

\begin{tabular}{lcc} 
Ear discharge & 1 & 0.5 \\
Runny nose & 2 & 1.1 \\
Sneezing & 3 & 1.6 \\
Tinnitus & 2 & 1.1 \\
\hline ENT disease & & \\
Ear disease & 44 & $47.3 \%$ \\
Nose disease & 24 & $25.8 \%$ \\
& & \\
Throat disease & 25 & $26.9 \%$ \\
\hline
\end{tabular}

Based on table 1, among 188 students, the number of male students was more than female with 98 students (52.1\%). Age of the students was mostly 14 years old, with 76 students (40.4\%). 150 students $(79.8 \%)$ did not have any complaint about their ear, nose, and throat. The most common chief complaint of the students was ear fullness with 15 students (8.0\%). Based on the examination, ear disease was the most findings with 44 students $(47.3 \%)$, followed by throat disease with 25 students $(26.9 \%)$, and nose disease with 24 students $(25.8 \%)$.

Table 2. Distribution of Students in Letjen Jamin Ginting Junior High School, Berastagi based on Ear Examination's Result

\begin{tabular}{lcc}
\hline Examination's Result & N & \% \\
\hline Normal & 144 & 76,6 \\
Cerumen Impaction & 43 & 22,9 \\
Acute Otitis Media & 1 & 0,5 \\
\hline
\end{tabular}

Table 2 showed that about 144 students (76.6\%) with normal results of ear examination. Cerumen impaction was found in 43 students $(22.9 \%)$ with the common complaints were ear fullness, tinnitus, and itchy ear. Otitis media was found in 1 student (0.5\%). Students with cerumen impaction were treated with cerumen removal.

Table 3. Distribution of Students in Letjen Jamin Ginting Junior High School, Berastagi based on Nose Examination's Result

\begin{tabular}{lcc}
\hline Examination's result & $\mathbf{N}$ & $\mathbf{\%}$ \\
\hline Normal & 164 & 87,2 \\
Allergic Rhinitis & 10 & 5,3 \\
Turbinate Hypertrophy & 12 & 6,4 \\
Nasal polyps & 2 & 1,1 \\
\hline
\end{tabular}

It was shown in table 3 that 164 students $(87.2 \%)$ had normal results of nose examination. Turbinate hypertrophy was found in 12 students $(6.4 \%)$, slightly different from allergic rhinitis in 10 students $(5.3 \%)$. The lowest number was found for nasal polyps, which only found in 2 students $(1.1 \%)$.

Table 4. Distribution of Students in Letjen Jamin Ginting Junior High School, Berastagi based on Throat Examination's Result

\begin{tabular}{lcc}
\hline \multicolumn{1}{c}{ Examination's result } & N & \% \\
\hline Normal & 163 & 86,7 \\
Chronic Tonsillitis & 23 & 12,2 \\
Tonsillopharyngitis & 2 & 1,1 \\
\hline
\end{tabular}


Farhat Farhat et.al. Ent examination and cerumen removal in Letjen Jamin Ginting Junior High School

Table 4 shows the results of throat examination with normal results as the most common findings in all of the students $(86.7 \%)$. The abnormal results with high numbers of finding were chronic tonsillitis in 23 students (12.2\%). Tonsillopharyngitis was found in 2 students (1.1\%).

16 students were educated in Letjen Jamin Ginting Junior High School, Berastagi as the delegation of each class. The education is about ENT diseases which start from the anatomy of ear, nose, and throat. The definition, etiology, clinical manifestations, and treatment of the ENT diseases also become the subject of education. The evaluation was done after the education finished. Among 16 students, there were 8 students with $80 \%$ correct answers, 5 students with $70 \%$ correct answers, and 3 students with $60 \%$ correct answers.

Ear disease was a common occurrence in developing countries and mostly affected children (Sigdel and Nepali, 2012; Verina, 2015). A study by Fasunla et al. showed that patients with ear disease were 3136 people (62.7\%), nose disease was 1153 people (23\%), and throat disease was 479 people $(9,6 \%)$ (Fasunla et al., 2013). Sigdel et al. in their study found that 944 of 1632 patients affected ear disease. The most common finding was cerumen impaction which found in 315 people $(33,4 \%)$, followed by chronic suppurative otitis media in 229 peoples $(24,3 \%)$ and acute suppurative otitis media in 123 people $(13,0 \%)$ (Sigdel and Nepali, 2012). Results of the several studies above are relevant to the findings of this community service. The result showed that ear disease becomes the most findings with 44 of 188 students (47.3\%).

The ear canal contains a substance called cerumen that is a combination secretion of the sebaceous glands (sebaceous) glands and apocrine together with the results of the ear canal squamous epithelial desquamation. Wax is a natural substance found in the ear canal and plays a role in cleaning, protecting, and lubricating the ear canal. Cerumen is waterproof and has an acidic $\mathrm{pH}$. The nature of cerumen is hydrophobic and has the ability in a bacteriostatic or fungistatic activity to prevent infection (Gerchman et al., 2012).

Cerumen is the product of sebaceous glands and ceruminous glands secretions together with the desquamation of ear canal epithelium (Schwartz et al., 2017, Stránský et al., 2011). Cerumen is a normal substance in the ear canal (Munir and Clarke, 2012; Prowse and Mulla, 2014). Cerumen is divided by wet cerumen and dry cerumen according to the ethnic of the person. Wet cerumen is found in $90 \%$ black and white people. The combination of wet and dry cerumen was found in the population of the Middle East and Southeast Asia. Dry cerumen was common in the population of North China, Korea, and Japan (Sugiura et al., 2014).

Cerumen has bactericidal activity (Gerchman et al., 2012; Dhillon and East, 2013) as the protection film, which has an antimicrobial function and lubricates the ear canal. Cerumen entrap the dust and dirt, which then expelled from the ear canal through the epithelial migration and jaw movement such as during eating or talking (Poulton et al., 2015; Tuli, 2013). The use of cotton bud and hearing aid could lead to cerumen accumulation (Wright, 2015).

Cerumen accumulation could obstruct the ear canal and causes cerumen impaction (Eskelinen et al., 2014; Ulaganathan and Shalini, 2015). Cerumen impaction is the occlusion of the ear canal by cerumen, which leads to conductive hearing loss type (Pensak and Choo, 2014; Schwartz et al., 2017). Cotton bud using as the most predisposing factor for cerumen impaction (Snow and Wackym, 2009). The symptoms are ear fullness, hearing loss, tinnitus, itchy ear, and ear pain (Pensak and Choo, 2014; Krouse et al., 2017; Eziyi et al., 2011). The excess of cerumen should be removed because it caused inhibit the visualization of eardrum and audiology procedure such as accuracy of audiometry (Prowse and Mulla, 2014, Johnson et al., 2013).

Cerumen impaction or obstruction of the ear canal by cerumen is one cause of most types of conductive hearing loss. The cause of this disorder is the use of a cotton bud. Besides, some patients 
Farhat Farhat et.al. Ent examination and cerumen removal in Letjen Jamin Ginting Junior High School

tend to excessive cerumen production, which forms a hard wax and also disturbances in migration and extrusion cerumen. Symptoms of this disorder is hearing loss, a sense of fullness in the ear, itching, and pain (Eskelinen et al., 2014).

The diagnosis of cerumen impaction is based on history taking, physical examination such as ear canal inspection, otoscopy and hearing test with using tuning fork (Akotey et al., 2017; Stewart and Selesnick, 2011). The symptoms of cerumen impaction were taken by history taking. The patients will also admit the habit on using cotton bud, insert foreign bodies to the ear canal or use a hearing aid or earpiece (Linstrom and Sclafani, 2015; Akotey et al., 2017).

Cerumen impaction occurs up to $6 \%$ of the general population and becomes the most reason for primary care consultation (Brkic, 2010). It affects 10\% children and 5\% adults. This disease is frequently underdiagnosed and has not been treated, although it has a relatively high proportion (Fullington et al., 2017). Fuad et al. in their study in Kalesija, Bosnia and Herzuegowina community found 328 children with cerumen impaction and without significant difference of boys and girls prevalence (Brkic, 2010). Feder et al. found $17 \%$ or 385 of 2591 Canadian children and teenagers in 3 to 19 years old, which had cerumen impaction (Feder et al., 2017). Hussain et al. in their study found that from 270 children, 223 children $(82,6 \%)$ had normal otoscopy finding, 11 children $(4,1 \%)$ with excess cerumen, 23 children $(8,5 \%)$ with cerumen impaction and 13 children $(4,8 \%)$ with discharge or redness of eardrum. Amusa et al. found that the most findings for otoscopy in children were cerumen impaction (Amusa et al., 2013). It proves that cerumen impaction was the most clinical findings for ear disease (Hussein et al., 2018). Ibiam et al. found that cotton bud using as the most predisposing factor in 338 of 3375 patients in ENT clinic (Ibiam et al., 2014). The studies above were similar in the findings of this community service, which showed cerumen impaction as the most findings ear disease with 43 students $(22,9 \%)$.

Indication of intervention and treatment of cerumen impaction is when a patient has symptoms, including ear pain or pressure, fullness in the ears, and hearing loss. However, the therapy is usually not justified for excessive cerumen without symptoms or when the ability to examine the ear is not compromised. Special consideration is needed for patients who cannot tell the symptom, including infants and patients with cognitive impairment, as well as those with structural abnormalities of the ear canal, immunosuppression, anticoagulation therapy, diabetic and non-intact tympanic membrane. Patients, including children, who wear hearing aids are at higher risk for cerumen impaction and should receive regular check-up and treatment if necessary to optimize the hearing efficiency (Hackell, 2017).

The treatment for cerumen impaction was cerumen removal performed by a physician with careful action. Cerumen removal could be done with manual extraction, irrigation, and using chemical substances. Manual extraction is done using cerumen hook or ear suction (Bansal, 2012). Hard cerumen is softening with chemical substances such as glycerin or hydrogen peroxide so it could be removed by manual extraction (Snow and Wackym, 2009; Linstrom and Sclafani, 2015; Griffin and Anderson, 2019). Failure to complete the first-line treatment of impacted should ask for a referral of patients to the doctor with specialized equipment and training in this procedure (Hackell, 2017).

Inserting things in the ear should be avoided. Some earwax may out on cotton, bobby pins, paperclips, or other items, but in reality, it just pushes the earwax back more in-depth into the ear, which lead problems. It also hurt the ears by putting or inserting the hole in the eardrum, cutting or scratching the ear canal skin, or even cause ear infections (Krouse et al., 2017).

There was no abnormality in the nose examination of the students. Turbinate hypertrophy, allergic rhinitis, and nasal polyps were the abnormal findings in the nose examination of the students, with turbinate hypertrophy as the most significant number with 12 out of $164(6.4 \%)$ students. 
Farhat Farhat et.al. Ent examination and cerumen removal in Letjen Jamin Ginting Junior High School

In table 3 , there were 164 students $(87.2 \%)$ had normal results of nose examination. Turbinate hypertrophy was found in 12 students (6.4\%), slightly different from allergic rhinitis with 10 students (5.3\%). The lowest number was found for nasal polyps, which found in 2 students $(1.1 \%)$.

The abnormalities that could occur in the nose is turbinate hypertrophy, which can cause upper airway obstruction and all the accompanying symptoms that vary from less realized until the disconcerting quality of life. According to one study in Europe, it is known that $20 \%$ of patients with chronic nasal obstruction caused by turbinate hypertrophy (Mrig et al., 2009). The ENT clinic in Tugurejo Hospital on January-December 2015, the proportion of patients with inferior turbinate hypertrophy by $5.9 \%$ or 166 outpatients (Cahyaningtyas, 2017).

From all the abnormalities findings of the throat examination of the students, chronic tonsillitis was by far the largest in number. Tonsillitis is the most common disease of all diseases recurrent throat. Chronic tonsillitis generally occurs due to complications of acute tonsillitis, especially those that do not receive adequate treatment. In addition to the treatment of acute tonsillitis inadequate, predisposing the onset of other chronic tonsillitis is poor oral hygiene, physical fatigue, and some foods.

In Indonesia, chronic tonsillitis is one of the most often ENT diseases which mainly found in children. One study about the characteristics of patients with chronic tonsillitis indicated in hospitals tonsillectomy Raden Mattaher Jambi, 30 samples were obtained from the population. Most of them were aged 5-14 years (50\%), female gender (56.7\%) and had complaints of pain in the throat or pain swallowing (100\%) (Sapitri, 2013). Chronic tonsillitis in children is most prevalent between the ages of 10-14 years. In children, most commonly found in the female sex. The chief complaint of patients Chronic tonsillitis in children who are at most painful swallowing repeatedly (Fakh et al., 2016).

The cerumen removal to the students with cerumen impaction was done in this community service.

\section{CONCLUSION}

Ear disease was the most common findings in the students of Letjen Jamin Ginting Junior High School, Berastagi with 44 students (47.3\%). Cerumen impaction was found in 43 students $(22.9 \%)$ and had been treated with cerumen removal.

\section{ACKNOWLEDGMENT}

The author wants to express big gratitude towards Lembaga Pengabdian Masyarakat Universitas Sumatera Utara for the financial support for this community service, under the TALENTA Project 2019, No. 327/UN5.2.3.2.1/PPM/2019.

Also, credits for the hard work of the team consists of Wina Viqa Sari, Raudah Putri Syari, Sinta Azhary Ginting, Roni Hikmah Ramadhan, Fahrur Rozi and all the ENT residents of H. Adam Malik Hospital that have been participated in this event.

\section{REFERENCES}

Akotey, S. C., Adza, E. K., Awini, A., Cobbinah, J. B., Darko, K., Ador, E. W., Arckertson, L. P., Dadzie-Bonney, P., Adzoe, C. \& Asamoah, B. 2017. Significance of Ear Wax Impaction in School Children: A Case of Winneba West Circuit, Ghana. Significance, 35.

Amusa, Y., Adegbenro, C., Ogunniyi, G. \& Olarinoye, T. 2013. Characteristics and etiology of hearing loss among the School for the Deaf Children in Ife-Ijesha Senatorial District of Osun State, Nigeria. Journal of Community Medicine and Health Education, 3, 2161-0711.1000205.

Bansal, M. 2012. Diseases of ear, nose and throat. JP Medical Ltd. 
Farhat Farhat et.al. Ent examination and cerumen removal in Letjen Jamin Ginting Junior High School

Brkic, F. 2010. Significance of ear wax impaction in school children. Acta Medica Saliniana, 39, 23.

Cahyaningtyas, R. 2017. Perbedaan Kualitas Hidup Antara Penderita Hipertropi Konka Inferior Pra dan Pasca Operasi Reduksi Konka Metode Radiofrekuensi. Disertasi Fakultas Kedokteran Universitas Muhammadiyah Seamarang. Semarang.

Dhillon, R. S. \& East, C. A. 2013. Ear, Nose and Throat Head and Neck Surgery. Elsevier. London.

Eskelinen, S., Sailas, E., Joutsenniemi, K., HOLI, M. \& Suvisaari, J. 2014. Cerumen impaction in patients with schizophrenia. Clinical schizophrenia \& related psychoses, 8, 110-112.

Eziyi, J., Amusa, Y., Nwawolo, C. \& Ezeanolue, B. 2011. Wax Impaction in Nigerian School Children. East and central African journal of surgery, 16, 40-45.

Fakh, I. M., Novialdi, N., \& Elmatris, E. 2016. Karakteristik Pasien Tonsilitis Kronis pada Anak di Bagian THT-KL RSUP Dr. M. Djamil Padang Tahun 2013. Jurnal Kesehatan Andalas, 5(2).

Fasunla, A. J., Samdi, M. \& Nwaorgu, O. G. 2013. An audit of Ear, Nose and Throat diseases in a tertiary health institution in South-western Nigeria. Pan African Medical Journal, 14.

Feder, K. P., Michaud, D., McNamee, J., Fitzpatrick, E., Ramage-Morin, P. \& Beauregard, Y. 2017. Prevalence of hearing loss among a representative sample of Canadian children and adolescents, 3 to 19 years of age. Ear and hearing, 38, 7.

Fullington, D., Song, J., Gilles, A., Guo, X., Hua, W., Anderson, C. E. \& Griffin, J. 2017. Evaluation of the safety and efficacy of a novel product for the removal of impacted human cerumen. BMC Ear, Nose and Throat Disorders, 17, 5.

Gerchman, Y., Patichov, R. \& Zeltzer, T. 2012. Lipolytic, proteolytic, and cholesterol-degrading bacteria from the human cerumen. Current microbiology, 64, 588-591.

Griffin, J. \& Anderson, E. 2019. Novel Compositions and Methods for Cerumen Removal. Google Patents.

Hackell, J. M. 2017. Updated guideline advises on treating children with impacted cerumen.

Hussein, S. Y., Mahomed-Asmail, F. \& de jager, L. B. 2018. Hearing loss in preschool children from a low income South African community. International journal of pediatric otorhinolaryngology, 115, 145-148.

Ibiam, F., Nduagu, S., Obasikene, G. \& Mbata, G. 2014. Clinical Profile and Management Audit of Ear Wax Impaction in Owerri, South East Nigeria. Online Journal of Otolaryngology, 4, 154.

Johnson, C. E., Danhauer, J. L., Rice, E. N. \& Fisher, S. K. 2013. Survey of audiologists and cerumen management. American journal of audiology.

Krouse, H. J., Magit, A. E., O’Connor, S., Schwarz, S. R. \& Walsh, S. A. 2017. Plain Language Summary: Earwax (Cerumen Impaction). Otolaryngology-Head and Neck Surgery, 156, 30-37.

Linstrom, C. J. \& Sclafani, A. P. 2015. Total Otolaryngology-Head and Neck Surgery, New York, Thieme Medical Publishers, Inc.

Mrig, S., Agarwal, A. K., \& Passey, J. C. 2009. Preoperative Computed Tomographic Evaluation of Inferior Nasal Concha Hypertrophy and its Role in Deciding Surgical Treatment Modality in Patients with Deviated Nasal Septum. International Journal of Morphology, 27(2).

Munir, N. \& Clarke, R. 2012. Ear, nose and throat at a glance. John Wiley \& Sons.

Pensak, M. L. \& Choo, D. I. 2014. Clinical otology. Thieme. 
Farhat Farhat et.al. Ent examination and cerumen removal in Letjen Jamin Ginting Junior High School

Poulton, S., Yau, S., Anderson, D. \& Bennett, D. 2015. Ear wax management. Australian family physician, 44, 731.

Prowse, S. \& Mulla, O. 2014. Aural microsuction for wax impaction: survey of efficacy and patient perception. The Journal of Laryngology \& Otology, 128, 621-625.

Sapitri V. 2013. Karakteristik penderita tonsilitis kronis yang diindikasikan tonsilektomi Di RSUD Raden Mattaher Jambi (skripsi). Fakultas Kedokteran dan Ilmu Kesehatan Universitas Jambi. Jambi.

Schwaab, M., Gurr, A., Neumann, A., Dazert, S., \& Minovi, A. 2011. Human antimicrobial proteins in ear wax. European journal of clinical microbiology \& infectious diseases, 30(8), 997-1004.

Schwartz, S. R., Magit, A. E., Rosenfeld, R. M., Ballachanda, B. B., Hackell, J. M., Krouse, H. J., Lawlor, C. M., Lin, K., Parham, K. \& Stutz, D. R. 2017. Clinical practice guideline (update): earwax (cerumen impaction). Otolaryngology-Head and Neck Surgery, 156, S1-S29.

Sevy, J. O., \& Singh, A. 2017. Cerumen Impaction. StatPearls Publishing.

Sigdel, B. \& Nepali, R. 2012. Pattern of Ear Diseases among Paediatric ENT Patient: An Experience from Tertiary Care Centre, Pokhara, Nepal. Journal of Nepal Paediatric Society, 32, 142-145.

Snow, J. \& Wackym, P. 2009. Ballenger's Otorhinolaryngology. 17. Head and Neck Surgery. People's Madical Publishing House. Shelton-Connecticut.

Stewart, M. G. \& Selesnick, S. H. 2011. Differential Diagnosis in Otolaryngology: Head and Neck Surgery, Thieme.

Stránský, K., Valterová, I., Kofroňová, E., Urbanová, K., Zarevúcka, M. \& Wimmer, Z. 2011. Nonpolar lipid components of human cerumen. Lipids, 46, 781-788.

Sugiura, S., Yasue, M., Sakurai, T., Sumigaki, C., Uchida, Y., Nakashima, T. \& Toba, K. 2014. Effect of cerumen impaction on hearing and cognitive functions in J apanese older adults with cognitive impairment. Geriatrics \& gerontology international, 14, 56-61.

Tuli, L. C. B. 2013. Textbook Of Ear, Nose and Throat. Jaypee Brothers Medical Publishers (P) Ltd. India. 